\title{
Thermal Change for Photovoltaic Panels and Energy Effects
}

\author{
N. Imal, S. Hasar, H. Çınar and E. Sener
}

\begin{abstract}
Photovoltaic panels (solar cells), they receive photon energy from sunlight, convert them to electrical energy by the semiconductor structural features. Photovoltaic panels produce a voltage, depending on the change of functional sunlight exposure. Produced voltage and determining of provided electrical power, must be dealt with the physical parameters that uses the concepts of light and temperature. In this study, usage of monocrystalline and polycrystalline structured photovoltaic panels electrical energy conversion for different atmospheric temperature and different sunlight intensity are studied. With the realization of the applications, photovoltaic panels' thermal change effects upon the energy production is discussed. With the conclusions obtained from the research applications and analyses, for heat exchange in photovoltaic panels to effects upon energy production, the obtained principles of functional changes are interpreted.
\end{abstract}

Index Terms-Photovoltaic panel, solar energy, power

\section{INTRODUCTION}

A $\mathrm{S}$ working structure, photovoltaic panels are to interact with sunlight. Sun, as a result of events occurring as core fusion, inherently spread light energy to its surrounding. Because, our world is a part of the solar system, it is continuously exposed to this interaction of light. For that reason, solar energy does not require any resources for the production according to other energy production sources. As a result of above, they are intensely preferred [1].

Crystalline and thin-film silicon solar cells are the state of art technology and they have a great potential for future energy production. They have many structure types [16]. This work includes monocrystalline and polycrystalline comparison within.

In this study, samples of monocrystalline and polycrystalline photovoltaic panels, according to previous studies, positioned in a certain direction and angle; afterwards, applications were performed [2].

N. Imal, Electrical Electronic Engineering Department, University of Bilecik Seyh Edebali, Bilecik, Turkey, (e-mail: nazim.imal@bilecik.edu.tr).

S. Hasar, Osmaneli Vocational High School, University of Bilecik Seyh Edebali, Bilecik, Turkey, (e-mail: sahabettin.hasar@bilecik.edu.tr).

H. Çınar, University of Bilecik Seyh Edebali. Bilecik, Turkey, (e-mail: harun.cinar@bilecik.edu.tr).

E. Sener, Electrical Electronic Engineering Department, University of Bilecik Seyh Edebali. Bilecik, Turkey, (e-mail: eralp.sener@bilecik.edu.tr).
With the panels used in the applications;

- For fixed temperature conditions, effects of energy conversion related to the changes in light parameters,

- For the fixed light intensity, effects to energy conversion of the changes in temperature parameters,

were studied [3-4].

In this study, for electrical energy generation in photovoltaic panels; depending the light intensity, by direct exposure of sun and absorption of the photon are considered to be effectively to what extent. Of which monocrystalline and polycrystalline panels is to have more electrical power generation capacity upon the parameters effecting the efficiency, investigations were carried out. In figure 1, it is seen photovoltaic panels used in the studies.

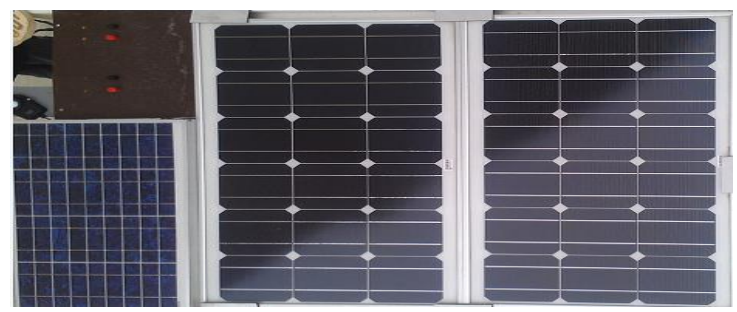

Fig.1. Monocrystalline and polycrystalline PV panels

In literature, a yearlong test has shown that the monocrystalline cells have higher efficiency than polycrystalline cells. It is shown that average module efficiency of $11.8 \%$ for monocrystalline and $11.5 \%$ for polycrystalline cells [14]. Also effects of irradiance and temperature can be calculated by formulas and using dark current values [15-16].

\section{PHOTOVOLTAIC PANELS}

Photovoltaic energy production by light excitation to electronic semiconductor components are provided with a potential difference occurring in the electrical energy levels. In a photovoltaic panel that contains silicon crystal, the substrate is covered with the P-type material, the upper layer is covered with N-type material that emitting chemical alloys of freeelectron such as phosphorus, antimony or arsenic. The gaps between the photovoltaic cells, coated with a material as aluminum, gallium, indium; formation of traces between cells is provided. Thus, with light exposure of them, the passing of 
electrons to the substrate of the " $P$ " is provided. These electrons have the ability to move on serial and parallel roads obtained in photovoltaic panels. So, creating "I" current by " $E^{\prime \prime}$ emf in photovoltaic panel, electrical energy production can be achieved. Although there are many photovoltaic panels that improved and being developed is present, here are the most widely known and used types are discussed. Moreover in figure 2 , visual images of which belong to these products are shared [5-6].

- Monocrystalline silicon photovoltaic panels: High purity parts of the silicon structure by means of subjecting "Czochralski pulling" and "floating zone" process, Mono crystalline silicon photovoltaic cells are made from very efficient, yield values can reach $18 \%$.

- Polycrystalline silicon photovoltaic panels: Despite the high efficiency of the monocrystalline silicon solar panels, due to the difficulties and high costs of production, simple structure than single crystal silicon of "Czochralski", polycrystalline silicon structures have been developed. Although energy production efficiency of "Polycrystalline Silicon Structure" is low $(8-10 \%)$, due to advantages of easier and lower cost of production they are preferred.

- Amorphous - silicon photovoltaics panels: They are produced by placing the amorphous silicon vapor and window films on to the stainless steel that few micrometers thick. When compared to the mono and poly crystalline structures, much less silicon structure (as 1\%) is required. Although, yields are low (as 4$5 \%$ ), because of have much lower cost per watt compared to other structures, it makes them advantageous.

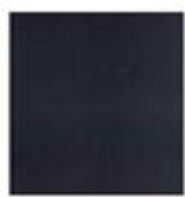

Thin Film

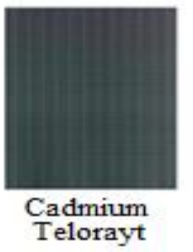

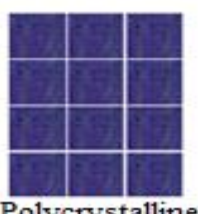

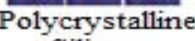
Silicon
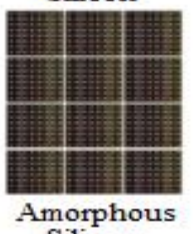

Silicon

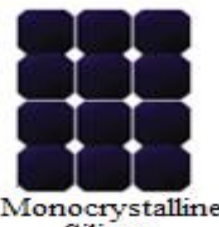
Silicon

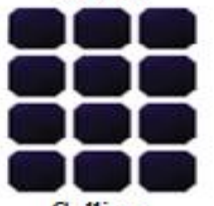

Gallium Arsenide
Fig.2. Photovoltaic panel types

- Gallium arsenide photovoltaic panels: The highest yield $(22 \%)$ owner of photovoltaic structures includes single-crystal gallium arsenide. Despite the high efficiency, also high costs lead to less preference.

- $\quad$ Thin film photovoltaic panels: It can be produced on cross section of very thin, such as cadmium sulfide, amorphous silicon, copper-indium-diselenide and e.t.c are polycrystalline structures in large surface areas. Although it has approximately $10 \%$ efficiency, it has low cost, and if it can be developed in many buildings exposed to sunlight, they can be used as roofing materials. They are the major advantages.

- Cadmium telluride photovoltaic panels: They are crystal structures that compound form of cadmium and tellurium. They are semiconductor structures that produced with layered superpose of cadmium sulfide and their efficiency approaches to $19 \%$.

\section{APPLICATION ANALYSIS OF ELECTRICITY GENERATION IN MONOCRYSTALLINE AND POLYCRYSTALLINE PANELS}

In this performed study, according to the many operating conditions, the most preferred monocrystalline and polycrystalline photovoltaic panels are placed in order to more sun seeing places, fixed in most suitable position and electric power generation analyzes were performed. Prior to the application, reviewing of the literature on the subject in preparation, work planning had been done [7-8-9-10-11-1213].

In the study, using one polycrystalline panels and two monocrystalline panels which connected in series, applications were made. Specifications of used materials in practice in table 1 and table 2. For applications, the image of the products used in construction is shown in figure 3 .

TABLE I

CHARACTERISTICS OF MONOCRYSTALLINE PHOTOVOLTAIC PANELS

\begin{tabular}{|c|c|}
\hline Panel Model & $\begin{array}{c}\text { ANALES } \\
\text { OKDA - } 18 \\
\end{array}$ \\
\hline Maximum Power (Pmpp) & $66,65 \mathrm{~W}$ \\
\hline Tolerance of Power & $+/-5 \%$ \\
\hline Rated Voltage (Vmpp) & $8,63 \mathrm{~V}$ \\
\hline Rated Current (Impp) & $7,72 \mathrm{~A}$ \\
\hline $\begin{array}{l}\text { Open Circuit Voltage } \\
\text { (VOC) }\end{array}$ & $11,23 \mathrm{~V}$ \\
\hline Short Circuit Current (ISC) & $8,31 \mathrm{~A}$ \\
\hline Max. System Voltage & $1000 \mathrm{~V}$ \\
\hline
\end{tabular}

TABLE II

CHARACTERISTICS OF POLYCRYSTALLINE PHOTOVOLTAIC PANELS

\begin{tabular}{|c|c|}
\hline Panel Model & Conergy Q 30PA \\
\hline Maximum Power (Pmpp) & $30 \mathrm{~W}$ \\
\hline Tolerance of Power & $+/-5 \%$ \\
\hline Rated Voltage (Vmpp) & $16,5 \mathrm{~V}$ \\
\hline Rated Current (Impp) & $1,83 \mathrm{~A}$ \\
\hline Open Circuit Voltage (VOC) & $20,0 \mathrm{~V}$ \\
\hline Short Circuit Current (ISC) & $2,0 \mathrm{~A}$ \\
\hline Max. System Voltage & $600 \mathrm{~V}$ \\
\hline
\end{tabular}




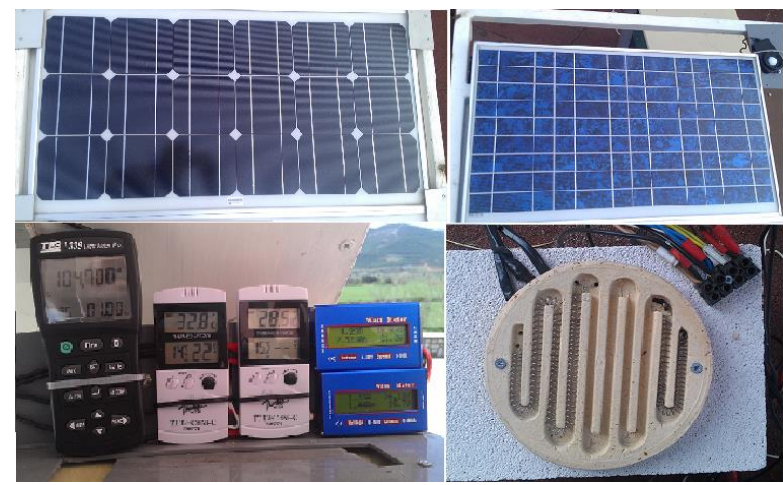

Fig. 3. Application equipments

At the graphics below between figure 4 and figure 15, for monocrystalline and polycrystalline photovoltaic panels, variance graphics of electrical energy production application analysis is shown. The nonlinearity seen in these measurements are caused by color spectrum of the light and momentarily deviation in photon distribution.

\section{A. ANALYSIS OF ELECTRICAL ENERGY GENERATION IN MONOCRYSTALLINE PANELS}

In figure 4, figure 5 and figure 6 , for monocrystalline panel, power changes seen for fixed illumination and different temperature conditions. In this variation graphics, it emerges that power decreases as long as temperature increases. This is caused by increasing resistance values of the semiconductor structure and resistance value of connection path according to temperature.

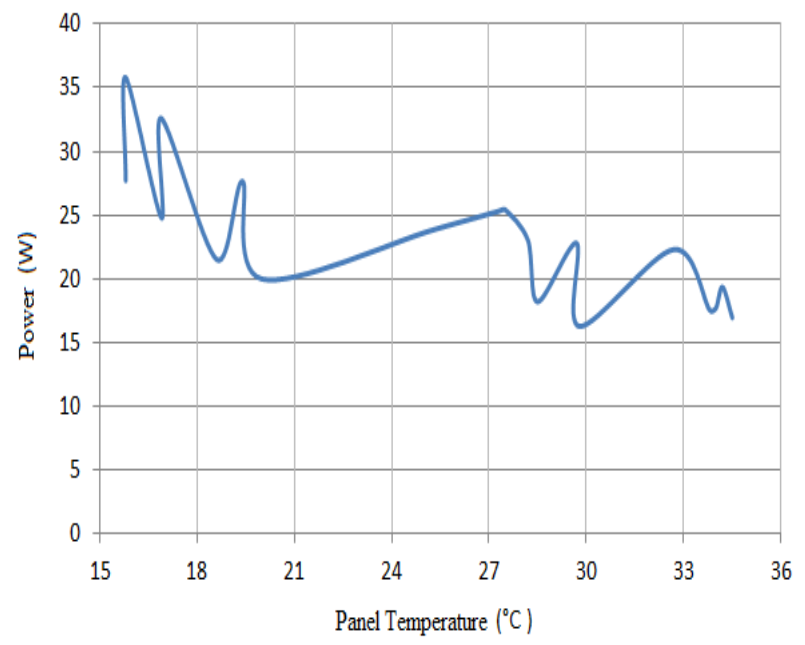

Fig. 4. For mono crystalline panel: while $\mathrm{Icd} \cong 30.000 \mathrm{Cd}, \mathrm{P}=\mathrm{f}(\mathrm{Tp})$ graph)

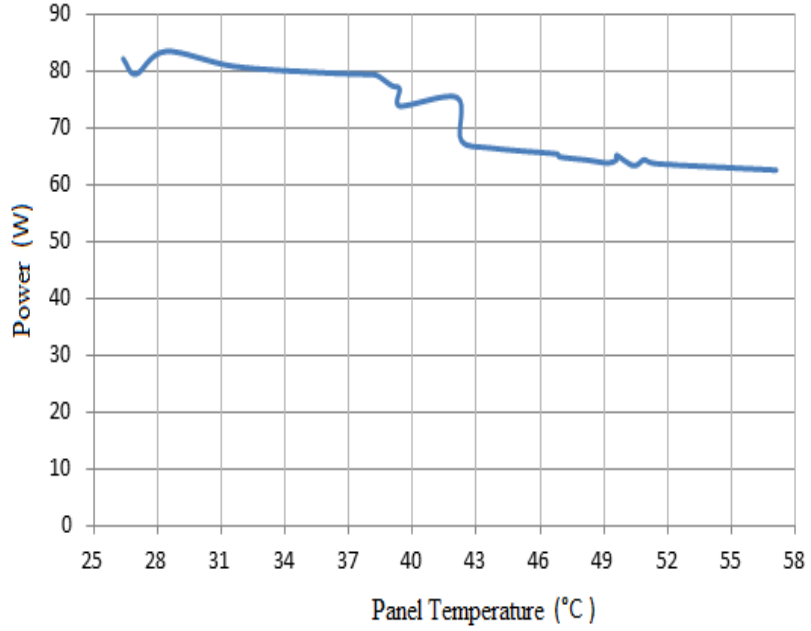

Fig. 5. For monocrystalline panel: while $\mathrm{Icd} \cong 90.000 \mathrm{Cd}, \mathrm{P}=\mathrm{f}(\mathrm{Tp})$ graph

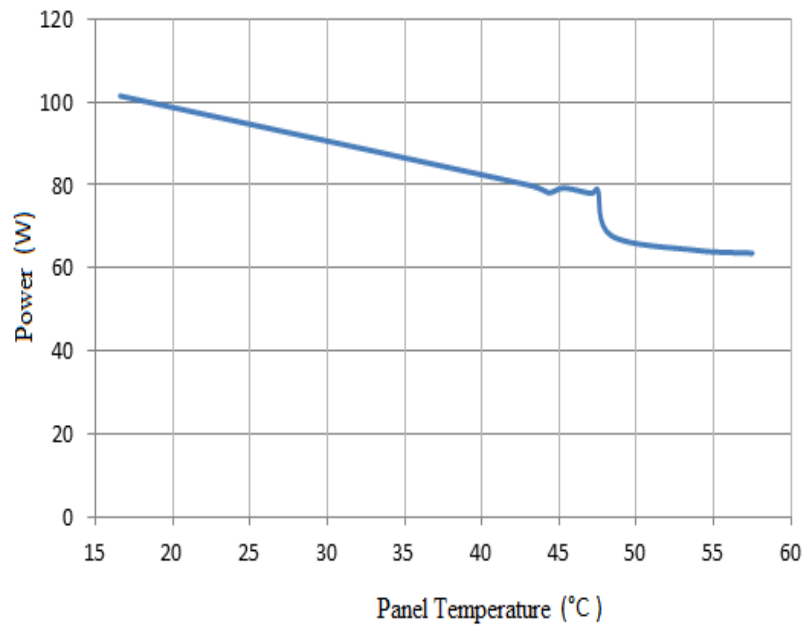

Fig. 6. For monocrystalline panel: while $\mathrm{Icd} \cong 130.000 \mathrm{Cd}, \mathrm{P}=\mathrm{f}(\mathrm{Tp})$ graph

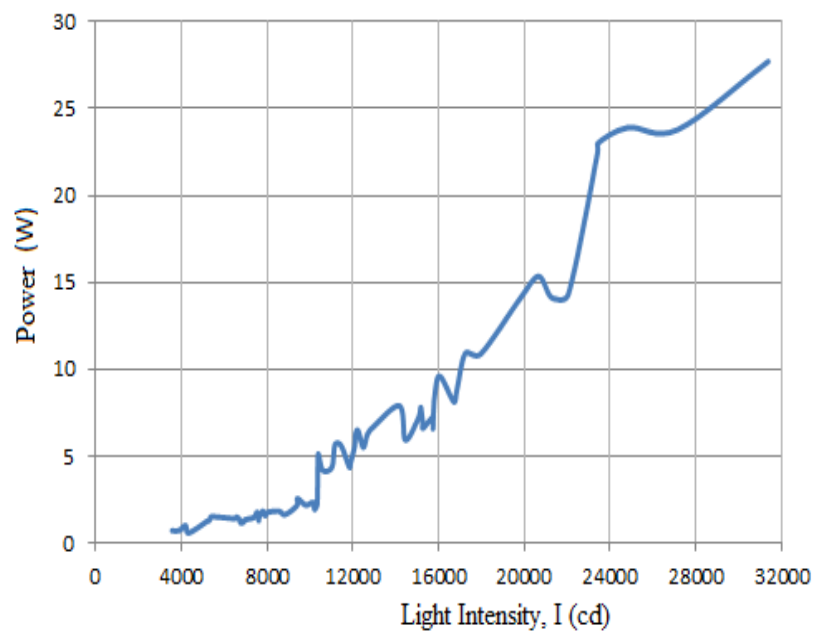

Fig. 7. For monocrystalline panel: while $\mathrm{Tp} \cong 15^{\circ} \mathrm{C}, \mathrm{P}=\mathrm{f}\left(\mathrm{I}_{\mathrm{CD}}\right)$ graph 
In figure 7, figure 8 and figure 9, for monocrystalline panel, power changes seen for fixed temperature and different illumination conditions. In this variation graphics, it emerges that power increases as long as temperature increases. This is caused by fixed resistance values of the semiconductor structure and resistance value of connection path according to fixed temperature and also increasing illumination provides more photons for energy conversion. In figure 7, the lesser energy production for low panel temperature is caused by lack of photons at the time of measurement.

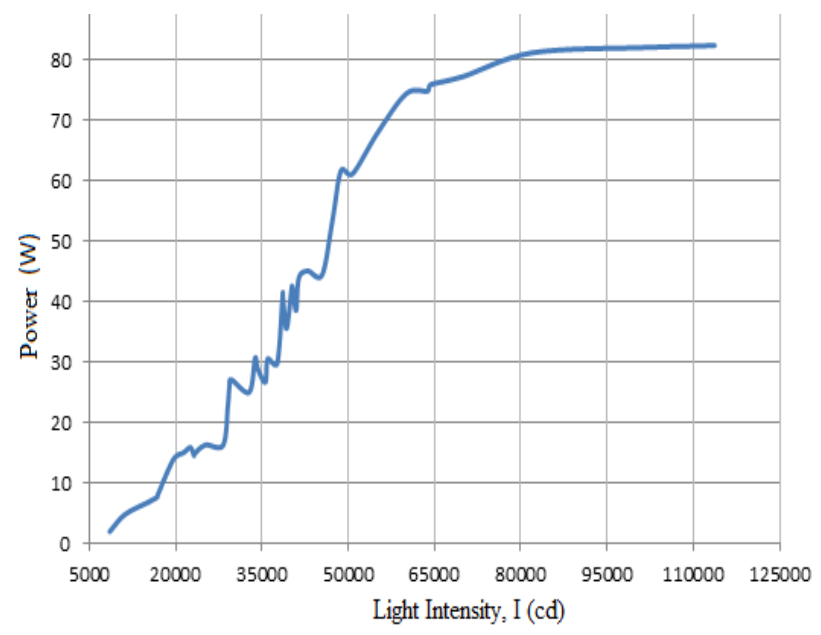

Fig. 8. For monocrystalline panel: while $\mathrm{Tp} \cong 30^{\circ} \mathrm{C}, \mathrm{P}=\mathrm{f}\left(\mathrm{I}_{\mathrm{CD}}\right)$ graph

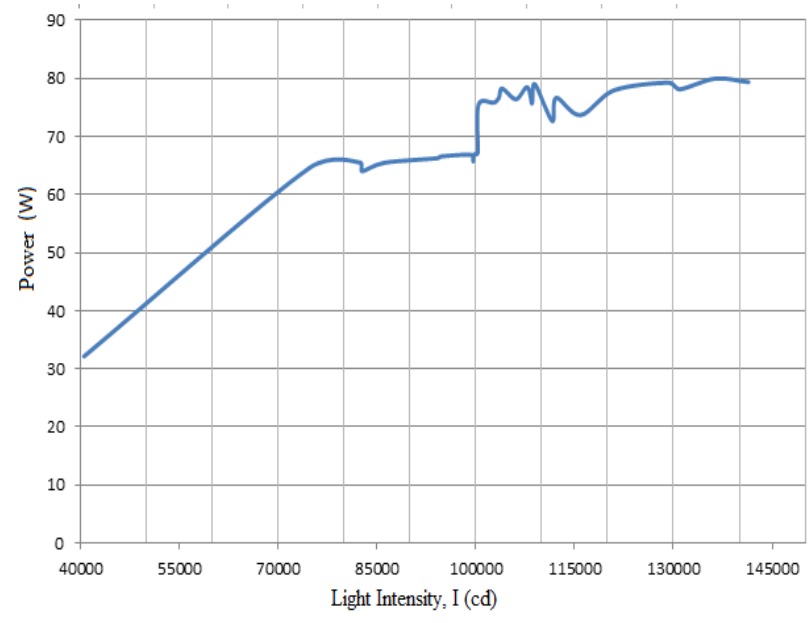

Fig. 9. For monocrystalline panel: while $\mathrm{Tp} \cong 45^{\circ} \mathrm{C}, \mathrm{P}=\mathrm{f}\left(\mathrm{I}_{\mathrm{CD}}\right)$ graph

\section{B. ANALYSIS OF ELECTRICAL ENERGY GENERATION IN POLYCRYSTALLINE PANEL}

In figure 10, figure 11 and figure 12 , for polycrystalline panel, power changes seen for fixed illumination and different temperature conditions. In this variation graphics, it emerges that power decreases as long as temperature increases. This is caused by increasing resistance values of the semiconductor structure and resistance value of connection path according to temperature.

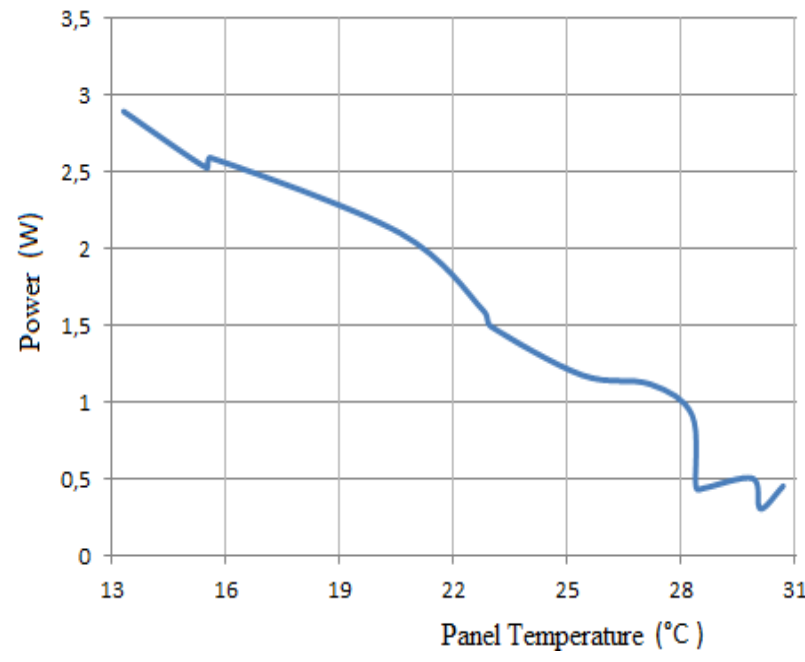

Fig. 10. For polycrystalline panel: while $\mathrm{Icd} \cong 30.000 \mathrm{Cd}, \mathrm{P}=\mathrm{f}(\mathrm{Tp})$ graph

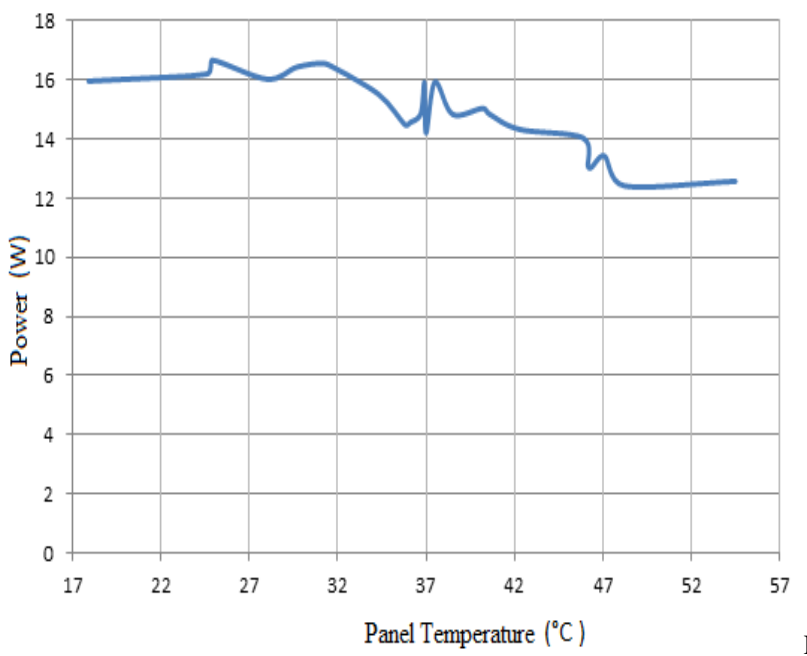

11. For polycrystalline panel: while $\mathrm{Icd} \cong 90.000 \mathrm{Cd}, \mathrm{P}=\mathrm{f}(\mathrm{Tp})$ graph

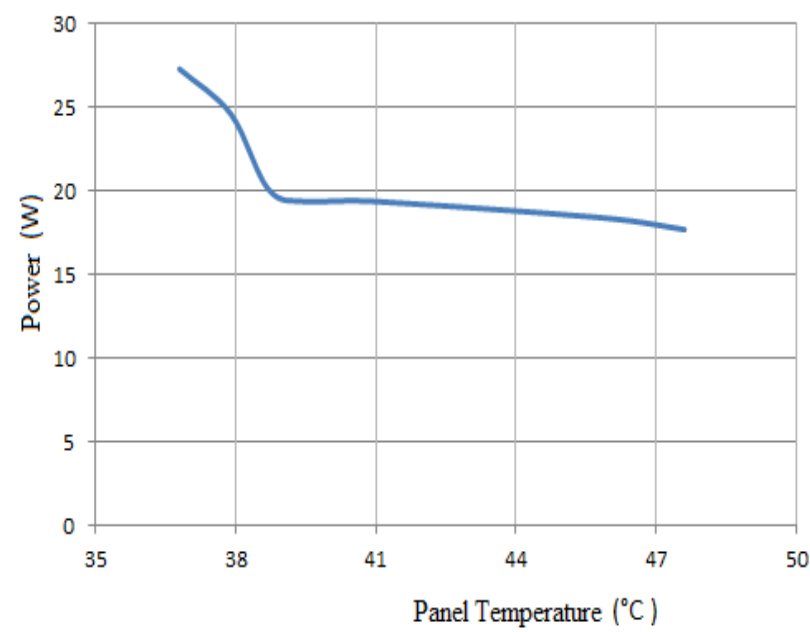

Fig. 12. For polycrystalline panel: while $\mathrm{Icd} \cong 130.000 \mathrm{Cd}, \mathrm{P}=\mathrm{f}(\mathrm{Tp})$ graph 
In figure 13, figure 14 and figure 15 , for polycrystalline panel, power changes seen for fixed temperature and different illumination conditions. In this variation graphics, it emerges that power increases as long as temperature increases. This is caused by fixed resistance values of the semiconductor structure and resistance value of connection path according to fixed temperature and also increasing illumination provides more photons for energy conversion. In figure 13, the lesser energy production for low panel temperature is caused by lack of photons at the time of measurement.

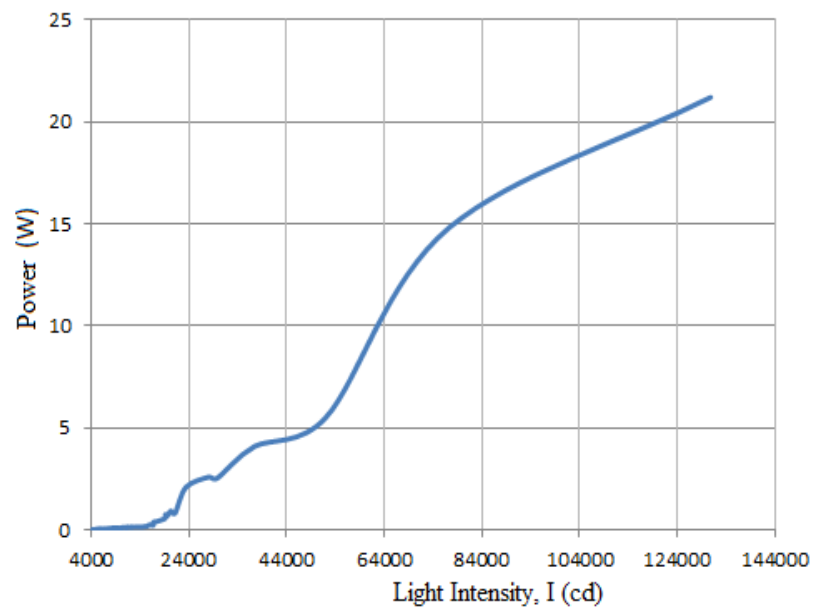

Fig. 13. For polycrystalline panel: while $\mathrm{Tp} \cong 15^{\circ} \mathrm{C}, \mathrm{P}=\mathrm{f}\left(\mathrm{I}_{\mathrm{CD}}\right)$ graph

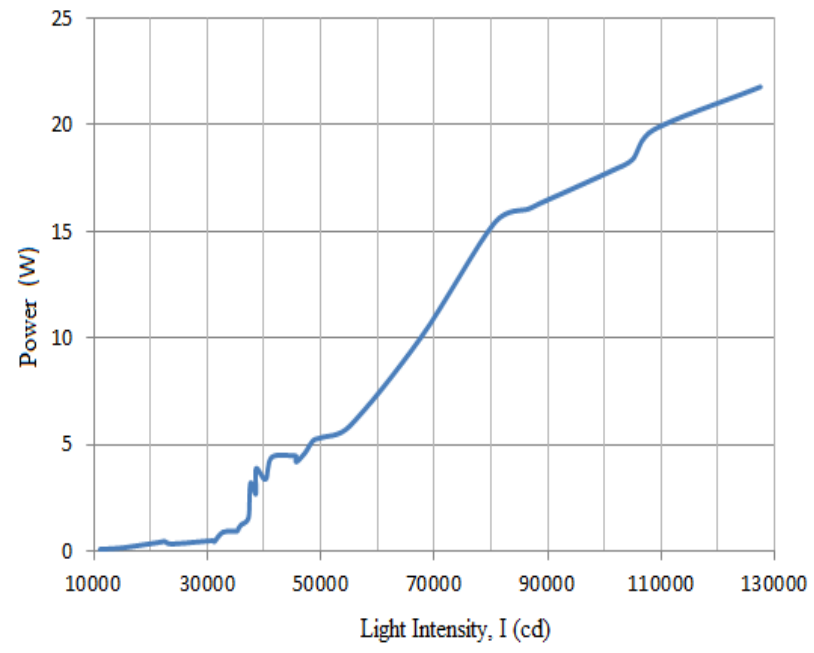

Fig. 14. For polycrystalline panel: while $\mathrm{Tp} \cong 30^{\circ} \mathrm{C}, \mathrm{P}=\mathrm{f}\left(\mathrm{I}_{\mathrm{CD}}\right)$ graph

Mathematical variance tables of the acquired data from the applications are shown in Table 3. The power values of the panels which are not tested for irradiation and temperature changes can be calculated using those functions.

For example; for a monocrystalline panel, for fixed light intensity at $30000 \mathrm{Cd}$, using the power function related to temperature shown in table 3 the value of power at 30 degrees $\left(\mathrm{P}=0,0116 * \mathrm{Tp}^{2}-1,143 * \mathrm{Tp}+44,333\right)$ can be calculated as 20,48 watts, and at 60 degrees as 17,51 watts.

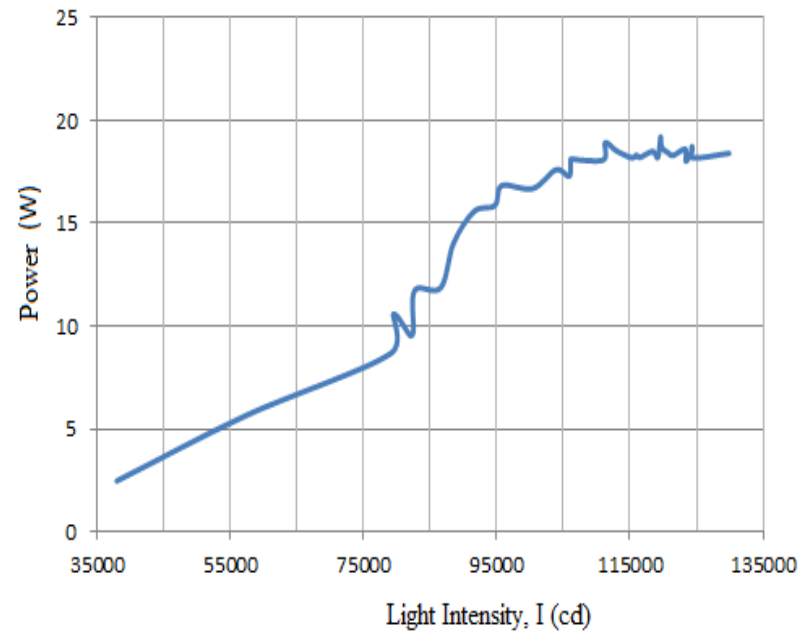

Şekil 15. For poly cristalline panel: while $\mathrm{Tp} \cong 45^{\circ} \mathrm{C}, \mathrm{P}=\mathrm{f}\left(\mathrm{I}_{\mathrm{CD}}\right)$ graph

TABLE III

MATHEMATICAL EXPRESSION OF THE APPLICATION DATA

\begin{tabular}{|c|c|c|}
\hline $\begin{array}{l}\text { Panel } \\
\text { Type }\end{array}$ & Sabit ve $y=f(X)$ & Değişim Fonksiyonu \\
\hline \multirow{6}{*}{ 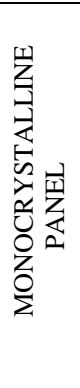 } & $\begin{array}{c}\mathrm{Icd} \cong 30.000 \mathrm{Cd} \\
\Rightarrow P=\mathrm{P}=\mathrm{f}(\mathrm{Tp})\end{array}$ & $\mathrm{P}=0,0116^{*} \mathrm{Tp}^{2}-143 * \mathrm{Tp}+44,333$ \\
\hline & $\begin{aligned} \mathrm{Icd} & \cong 90.000 \mathrm{Cd} \\
& =>P=\mathrm{f}(\mathrm{Tp})\end{aligned}$ & $\begin{array}{c}\mathrm{P}=-0,0074 * \mathrm{Tp}^{2}-0,2292 * \mathrm{Tp} \\
+94,878\end{array}$ \\
\hline & $\begin{array}{c}\text { Icd } \cong 130.000 \mathrm{Cd} \\
\quad=>P=f(\mathrm{Tp})\end{array}$ & $\begin{array}{c}\mathrm{P}=-0,0119 * \mathrm{Tp}^{2}-0,0955 \\
* \mathrm{Tp}+106,39\end{array}$ \\
\hline & $\begin{aligned} & \mathrm{Tp} \cong 15^{\circ} \mathrm{C} \\
\Rightarrow & \mathrm{P}=\mathrm{f}\left(\mathrm{I}_{\mathrm{CD}}\right)\end{aligned}$ & $\begin{array}{c}\mathrm{P}=0,00000003 * \mathrm{I}_{\mathrm{CD}}^{2}+0,0002 * \mathrm{I}_{\mathrm{CD}}- \\
0,9733\end{array}$ \\
\hline & $\begin{array}{l}\mathrm{Tp} \cong 30{ }^{\circ} \mathrm{C} \\
\Rightarrow>\mathrm{P}=\mathrm{f}\left(\mathrm{I}_{\mathrm{CD}}\right)\end{array}$ & $\begin{array}{c}\mathrm{P}=-0,00000001 * \mathrm{I}_{\mathrm{CD}}^{2}+0,0021 \\
* \mathrm{I}_{\mathrm{CD}}-26,099\end{array}$ \\
\hline & $\begin{array}{l}\mathrm{Tp} \cong 45^{\circ} \mathrm{C} \\
\Rightarrow \mathrm{P}=\mathrm{f}\left(\mathrm{I}_{\mathrm{CD}}\right)\end{array}$ & $\begin{array}{c}\mathrm{P}=-0,000000005 * \mathrm{I}_{\mathrm{CD}}{ }^{2}+0,0013 \\
* \mathrm{I}_{\mathrm{CD}}-12,317\end{array}$ \\
\hline \multirow{6}{*}{ 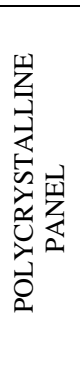 } & $\begin{array}{c}\mathrm{Icd} \cong 30.000 \mathrm{Cd} \\
\quad=>P=\mathrm{f}(\mathrm{Tp})\end{array}$ & $\mathrm{P}=-0,002 * \mathrm{Tp}^{2}-0,061 * \mathrm{Tp}+4,0271$ \\
\hline & $\begin{array}{c}\mathrm{Icd} \cong 90.000 \mathrm{Cd} \\
\quad>P=\mathrm{P}(\mathrm{Tp})\end{array}$ & $\begin{array}{c}\mathrm{P}=-0,0034 * \mathrm{Tp}^{2}+0,1163 * \mathrm{Tp} \\
+15,491\end{array}$ \\
\hline & $\begin{array}{l}\text { Icd } \cong 130.000 \mathrm{Cd} \\
\quad \Rightarrow P=f(T p)\end{array}$ & $\mathrm{P}=0,185 * \mathrm{Tp}^{2}-16,342 * \mathrm{Tp}+377,29$ \\
\hline & $\begin{array}{c}\mathrm{Tp} \cong 15^{\circ} \mathrm{C} \\
\Rightarrow>\mathrm{P}=\mathrm{f}\left(\mathrm{I}_{\mathrm{CD}}\right)\end{array}$ & $\begin{array}{c}\mathrm{P}=5 * 10^{-10} * \mathrm{I}_{\mathrm{CD}}{ }^{2}+0,0001 * \mathrm{I}_{\mathrm{CD}} \\
-1,1442\end{array}$ \\
\hline & $\begin{array}{l}\mathrm{Tp} \cong 30^{\circ} \mathrm{C} \\
\Rightarrow \mathrm{P}=\mathrm{f}\left(\mathrm{I}_{\mathrm{CD}}\right)\end{array}$ & $\begin{array}{c}\mathrm{P}=3 * 10^{-10} \mathrm{I}_{\mathrm{CD}}{ }^{2}+0,0002 * \mathrm{I}_{\mathrm{CD}} \\
-4,5996\end{array}$ \\
\hline & $\begin{aligned} & \mathrm{Tp}=45^{\circ} \mathrm{C} \\
& \Rightarrow>\mathrm{P}=\mathrm{f}\left(\mathrm{I}_{\mathrm{CD}}\right)\end{aligned}$ & $\begin{array}{c}\mathrm{P}=-10^{-9} * \mathrm{I}_{\mathrm{CD}} 2+0,0004 * \mathrm{I}_{\mathrm{CD}} \\
-12,914\end{array}$ \\
\hline
\end{tabular}

\section{CONCLUSIONS}

As the result of the examination, about the electrical energy obtained from the photovoltaic panels;

- Monocrystalline panels provide more electrical energy conversion than polycrystalline panels.

- Fixed $\mathrm{I}_{\mathrm{cd}}$ values as shown above, as seen in $P=f(T p)$ graphics, increased temperature causes power to decrease according to the semiconductor structure and resistance increment at the connection lines.

\begin{tabular}{llllll}
\hline Copyright (C) BAJECE & ISSN: 2147-284X & Special Issue 2015 & Vol.3 & No.4 & http://www.bajece.com
\end{tabular}


- $\quad$ Fixed $T p$ values as shown above, as seen in $P=f\left(I_{C D}\right)$ graphics, increased irradiance causes power to increase.

- As shown in Table 3, using $P=f(T p)$ function, for monocrystalline and polycrystalline panels, premeasured power values depending on temperature can be guessed.

- As shown in Table 3, using $P=f\left(I_{C D}\right)$ function, for monocrystalline and polycrystalline panels, premeasured power values depending on illumination can be guessed.

- Harvesting solar power is direcly related to photon absorbtion,

- Indirect illuminated placement causes low electrical harvesting due to lack of photon.

- In spite of photon absorptions positive effect on energy harvesting, increasing temperature of solar panel can effect the transformation efficiency negatively due to the semiconductor structure and resistance increment at the connection lines.

- Providing natural heat transfer from the solar panel at the mounting process will increase the photovoltaic panel's efficiency.

- In architectural applications, increasing heat of the solar panels may cause high temperature, so that situation must be considered for fire safety.

- Solar power plant establishments must be settled for the most vertical irradiated positions and not high temperature places.

\section{ACKNOWLEDGMENT}

The study is selected from National Engineering Research Symposium 2015 (Ulusal Mühendislik Araştırmaları Sempozyumu) UMAS 2015 (Duzce University).

\section{REFERENCES}

[1] Güçlü, S., (2009). Dumlupınar Üniversitesi Merkez Kampus çevre aydınlatma elektrik enerjisinin güneş enerjisi ile sağlanması, Dumlupınar Ünv. Fen Bil. Ens. Elk-Elkt. Müh., Kütahya.

[2] Turhan, K., (2011). Fotovoltaik modüller için bir gerçek saha performans ölçüm platformunun tasarımı, kurulumu ve testleri, Enerji Enstitüsü, İTÜ, İstanbul.

[3] Öztürk, E., (2014). Fotovoltaik panellerin verimine modül sıcaklığının etkisinin deneysel olarak araştırılması, Karabük Ünv. Fen Bil. Ens. Elk-Elkt. Müh., Karabük.

[4] Aslan, C.O., (2011). Is1 etkisinin solar panel verimliliğine etkisinin incelenmesi, Marmara Ünv. Fen Bil. Ens. Mekatronik ABD, İstanbul.

[5] Muhtaroğlu, T. K., (2012). Güneş enerjisini elektrik enerjisine çeviren çevre dostu sistemin tasarlanması, Gazi Ünv. Fen Bil. Ens. Elk-Elkt. Müh., Ankara.

[6] Yusufoğlu, G., (2013). Şebeke elektriğinin bulunmadığı tarımsal alanlarda güneş enerjisiyle sulamanın yapılması, Marmara Ünv. Fen Bil. Ens. Makine Eğitimi ABD, İstanbul.

[7] Keçel, S., (2008). Türkiye'deki bölgesel sıcaklık değişimlerinin güneş panellerinin verimliliğine etkisi, Gazi Üniversitesi Endüstriyel Sanatlar Eğitim Fakültesi Dergisi, Sayı: 22, s.12-20.
[8] Sahri, A.,Toumi S., (2013). Temperature effects on the power production based Photovoltaic cells, University of Badji-Mokhtar, Annaba, Algeria.

[9] Werner, L., (1969). Temperature Cycling Effects on Solar Panels, TRW Systems, Redondo Beach, California.

[10] Balázs, P., (2014). Characterization of solar cells by thermal transient testing, Budapest University of Technology and Economics (BME), Department of Electron Devices, Budapest, Hungary.

[11] Temaneh-Nyah, C., (2015). An investigation on the effect of operating temperature on power out put of the Photovoltaic System, Department of Electronics and Computer Engineering, University of Namibia Faulty of Engineering and IT Ongwediva, Namibia.

[12] Iş̧1ker, Y., (2006). Fotovoltaik Panel Gücüne Etki Eden Çalışma Parametrelerinin Araştırılması, Makine Mühendisliği Bölümü, Harran Üniversitesi, Şanlıurfa.

[13] Altaş, İ., (1998), Foto voltaj Güneş Pilleri :Eşdeğer Devre Modelleri ve Günışı̆̆ı ile Sıcaklığın Etkileri, Elektrik-Elektronik Mühendisliği Bölümü ,Karadeniz Teknik Üniversitesi, Trabzon.

[14] Zain, Z.M., (2013), Grid Connected Monocrytalline and Polycrystalline Photovoltaic System: A Comparative Study on Performance

[15] Stutenbaeumer, Ulrich, (1999)"Equivalent model of monocrystalline, polycrystalline and amorphous silicon solar cells." Renewable Energy 18.4: 501-512.

[16] Green, Martin A. (2003)"Crystalline and thin-film silicon solar cells: state of the art and future potential." Solar energy 74.3181 192.

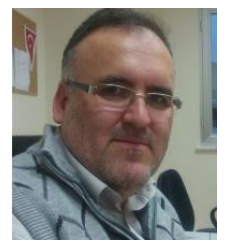

\section{BIOGRAPHIES}

Nazım İMAL was born in Samsun, Turkey, in 1970. He received the professional qualification in electrical department from the Gazi University, Ankara, in 1992. Ms.Sc. degree in Dumlupinar University, department of electronics and computer, completed in 1996, Ph.D. degree in electrical and electronics engineering, completed in Sakarya University. He has been Assistance Professor in Bilecik Seyh Edebali University since 2008.

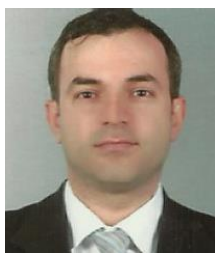

Şahabettin HASAR was born in Mardin, Turkey in 1978. He received the professional qualification in electrical department from the Gazi University, Ankara, in 2002. He has been a lecturer in Bilecik Seyh Edebali University since 2009 (Osmaneli Vocational High School).

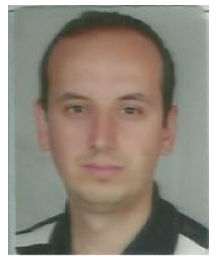

Harun ÇINAR was born in Bolu, Türkiye in 1984. He received the engineer qualification in electrical and electronics engineering from the Karaelmas University, Zonguldak, in 2006, Ms.Sc. degree in Energy Systems Engineering is ongoing in Bilecik S.E University. Working as an engineer in Bilecik S.E University.

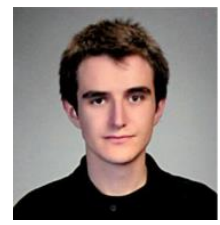

Eralp ŞENER was born in Eskişehir, Turkey in 1987. $\mathrm{He}$ received the engineer qualification in electrical and electronics engineering from the Anadolu University, Eskişehir, in 2011, Ms.Sc. degree in Energy Systems Engineering is ongoing in Bilecik S.E University. Working as a Teaching Assistant in Bilecik S.E University. 